\author{
Bartłomiej Łuć \\ ORCID 0000-0003-0798-675X \\ Uniwersytet Łódzki \\ Instytut Geografii Miast i Turyzmu \\ bartlomiej.luc@op.pl
}

\title{
PRZESTRZEŃ TURYSTYCZNA BARLINKA W KONTEKŚCIE UKŁADÓW MODELOWYCH
}

\begin{abstract}
Abstrakt: Artykuł charakteryzuje przestrzeń turystyczną Barlinka w kontekście układów modelowych. Na podstawie przeprowadzonych badań terenowych i licznych analiz atrakcji turystycznych oraz poszczególnych elementów zagospodarowania turystycznego autor dokonał porównania i dopasowania wspomnianej przestrzeni do układów modelowych, opracowanych przez S. LISZEWSKIEGO (1995) oraz B. WŁODARCZYKA (2011). Ponadto przedstawił poszerzoną analizę SWOT wspomnianej przestrzeni turystycznej Barlinka.
\end{abstract}

Słowa kluczowe: Barlinek, przestrzeń turystyczna, układ modelowy, infrastruktura turystyczna, atrakcja turystyczna.

\section{WPROWADZENIE}

Przestrzeń turystyczna i różnorodne związane $\mathrm{z}$ nią zjawiska stanowia przedmiot badań wielu naukowców. Tą tematyką interesują się osoby związane zarówno $z$ naukami geograficznymi, jak i socjologicznymi oraz ekonomicznymi. Rozważania nad przestrzenią turystyczną są szerokie i dość skomplikowane, bowiem jej struktura podlega bardzo dynamicznym przeobrażeniom. Ponadto często zmienia swój charakter, kształtowany przez takie czynniki, jak: elementy przyrodnicze oraz związane $\mathrm{z}$ działalnością człowieka (WŁODARCZYK 2011).

Jedną z pierwszych definicji przestrzeni turystycznej opracował już ponad 40 lat temu J.M. MIOSSEC (1976). Jego zdaniem jest to przestrzeń zlokalizowana jedynie na peryferiach centrum zamieszkania, $\mathrm{w}$ miejscach, gdzie możliwość pokonywania odległości umożliwia rozwój popytu turystycznego. A. JACKOWSKI i J. WARSZYŃSKA (1978) jako pierwsi uznali, że przestrzeń turystyczna jest częścią ogólnej przestrzeni geograficznej, w której zachodzą zjawiska turystyczne. Kilka lat później W.C. HuSBANDS (1983) stwierdził, że przestrzeń turystyczna obejmuje podsystem miejsc zamieszkania turystów, podsystem miejsc przyjmujących turystów oraz powiązania pomiędzy obydwoma tymi systemami. M. STALSKI (1984) za podstawowy element przestrzeni turystycznej uznał możliwość świadczenia usług i programów turystyczno-rekreacyjnych, jak również możliwość realizacji wypoczynku. Ponad 10 lat później S. LISZEWSKI (1995) uznał zaś, że przestrzeń turystyczna jest wyróżniającą się pod względem funkcjonalnym częścią całej przestrzeni geograficznej, kształtowanej przez elementy przyrodnicze oraz przez czynniki związane z działalnością człowieka. Jedną z najnowszych definicji przestrzeni turystycznej opracował B. WŁODARCZYK (2009). W jego opinii podstawowym czynnikiem, który pozwala daną przestrzeń zaklasyfikować jako przestrzeń turystyczną, jest występowanie zjawiska ruchu turystycznego. Innym dodatkowym warunkiem jest funkcjonowanie elementów zagospodarowania turystycznego. Obydwa te składniki decydują o wielkości i typie danej przestrzeni turystycznej. Badacz, podobnie jak S. LISZEWSKI (1995), uznał ją za część ogólnej przestrzeni geograficznej.

Niniejszy artykuł jest pewnego rodzaju poszerzeniem rozważań, zaprezentowanych przez autora $\mathrm{w}$ jego pracy magisterskiej pt. Atrakcyjność turystyczna Barlinka, która powstała w 2018 r. Głównym celem artykułu jest zaklasyfikowanie przestrzeni turystycznej Barlinka do rodzajów i układów modelowych miejskich przestrzeni turystycznych, sporządzonych przez S. LISZEWSKIEGO (1995) oraz B. WŁODARCZYKA (2011). Ponadto autor podjął również próbę opracowania 
poszerzonej analizy SWOT przestrzeni turystycznej Barlinka.

Badania terenowe przeprowadzono na przełomie lipca i sierpnia 2017 r. Zasięg przestrzenny badań obją granice administracyjne miasta Barlinek oraz miejscowości, w których mieszkają ankietowani turyści. Metody badawcze, wykorzystane przez autora, to przede wszystkim badania ankietowe przeprowadzone z przypadkowo spotkanymi mieszkańcami i turystami oraz inwentaryzacja terenowa walorów turystycznych i poszczególnych elementów zagospodarowania turystycznego. W badaniach ankietowych wzięło udział 216 mieszkańców Barlinka i 200 turystów. Badania te przeprowadzono głównie w okolicach rynku miejskiego i promenady nad Jeziorem Barlineckim. Ponadto na podstawie dokonanej inwentaryzacji terenowej i własnych obserwacji autor mógł opracować poszerzoną analizę SWOT przestrzeni turystycznej Barlinka i dokładnie scharakteryzować tę przestrzeń.

\section{CHARAKTERYSTYKA BARLINKA}

Barlinek jest miastem położonym w północno-zachodniej części Polski, w południowej części województwa zachodniopomorskiego, w powiecie myśliborskim. Stanowi siedzibę miejsko-wiejskiej gminy Barlinek (CzOPEK, PIESZCZACHOWICZ 2001). W roku 2017 Barlinek zamieszkiwało około 15 tys. mieszkańców, co czyniło go najludniejszym miastem $\mathrm{w}$ powiecie. Powierzchnia miasta wynosi blisko $17 \mathrm{~km}^{2}$.

Pod względem geograficznym Barlinek położony jest na Pojezierzu Myśliborskim i Równinie Gorzowskiej, nad rzekami Młynówką i Płonią oraz jeziorami Barlineckim, Chmielowym i Uklejno. Blisko $50 \%$ powierzchni miasta stanowią tereny leśne Puszczy Barlineckiej, objęte ochroną w postaci Barlinecko-Gorzowskiego Parku Krajobrazowego (PRZYBYLSKI, SKAZIŃSKI 2014). Puszcza ta stanowi duży kompleks leśny, rozciągający się na równinie sandrowej usypanej około 12 tys. lat temu przez wody odpływające $z$ lodowca (KONDRACKI 1998). Około 3\% powierzchni miasta stanowią jeziora, spośród których największym jest Jezioro Barlineckie (powierzchnia ok. 272 ha). Od strony północnej miasto graniczy z obszarami Doliny Płoni, słynącej z malowniczych wąwozów oraz kęp drzew i krzewów (PRZYBYLSKI, SKAZIŃSKI 2014).

O powstaniu Barlinka w głównej mierze zadecydowały bardzo korzystne uwarunkowania przyrodnicze w postaci bezpośredniego sąsiedztwa jeziora i puszczy, które zapewniały pożywienie i bezpieczeństwo. Pierwsze ślady osadnictwa datowane są już na okres neolitu i późniejszych epok brązu i żelaza (MIELCAREK, PRZYBYLSKI 2009). W średniowieczu tutejsze tereny wchodziły w skład państwa Piastów (MIELCAREK 2006). Za oficjalną datę utworzenia miasta uznawany jest rok 1278, kiedy margrabiowie brandenburscy wydali w Gorzowie akt lokacyjny miasta (PRZYBYLSKI, SKAZIŃSKI 2014). Najgorszym okresem w historii Barlinka był przełom XVI i XVII w., jako że wówczas miasto dotknęły liczne niszczycielskie pożary. Poważne zniszczenia nastąpiły również w trakcie wojny trzydziestoletniej. Barlinek odbudowano dopiero pod koniec wieku XVII (MiELCAREK 2006). Przełom XIX i XX w. zaś to czas największego rozkwitu miasta. Wówczas Barlinek uznawany był za znany niemiecki kurort turystyczny, zwany perłą Nowej Marchii. Obecnie miasto promowane jest jako europejska stolica nordic walkingu. Poza tym słynie również z przemysłu drzewnego i produkcji paneli podłogowych (tzw. deski barlineckiej).

\section{CHARAKTERYSTYKA ELEMENTÓW KSZTAETUJACYCH PRZESTRZEŃ TURYSTYCZNĄ BARLINKA}

Zdaniem B. WŁODARCZYKA (2011) do elementów kształtujących przestrzeń turystyczną należą:

- dziedzictwo przyrodnicze,

- dziedzictwo kulturowe (materialne i niematerialne),

- infrastruktura turystyczna (baza noclegowa, baza gastronomiczna, baza paraturystyczna, infrastruktura komunikacyjna),

- ludzie (turyści, osoby organizujące i zarządzające przestrzenią turystyczną).

Dziedzictwo przyrodnicze Barlinka kształtowane jest przede wszystkim przez Jezioro Barlineckie, które w opinii większości mieszkańców i turystów stanowi główną atrakcję turystyczną miasta. Obecnie fragment linii brzegowej tego jeziora położony na terenie miasta wynosi około 5,6 km, powierzchnia zaś - 162 ha. Ponadto na dziedzictwo to oddziałują Jezioro Chmielowe i jezioro Uklejno. Istotnym elementem są również lasy Puszczy Barlineckiej, objęte ochroną w postaci Barlinecko-Gorzowskiego Parku Krajobrazowego. Wśród elementów dziedzictwa przyrodniczego należy także uwzględnić tereny zieleni miejskiej, spośród których najbardziej znanym jest park im. Emanuela Laskera oraz pomniki przyrody, m.in. tzw. lipa równoleżnikowa. Na dziedzictwo przyrodnicze wpływa też panujący tu klimat, charakteryzujący się wyższymi średnimi rocznymi temperaturami w porównaniu ze średnimi krajowymi (powyżej $8,5^{\circ} \mathrm{C}$ ) oraz małą ilością opadów atmosferycznych, wynoszącą około $550 \mathrm{~mm}$ rocznie (BORYCZKA, STOPA-BORYCZKA 2005).

Analizując dziedzictwo kulturowe Barlinka stwierdzono, że kształtują je przede wszystkim zabytki. Z uwagi na dość burzliwą historię miasta zachowane zabytki pochodzą z okresu średniowiecza i z przełomu 
XIX i XX w. Wśród zabytków z wieków średnich z pewnością należy wymienić rynek miejski, kościół NMP i pozostałości murów obronnych. Z przełomu wieków XIX i XX zachowały się z m.in. kąpielisko „Pod Sosnami" oraz kościół św. Bonifacego. Ważną rolę odgrywają także niematerialne składniki dziedzictwa kulturowego. Są to głównie organizowane tu wydarzenia o charakterze kulturowym i sportowym, fabuły baśni i legend autorstwa Romany Kaszczyc oraz postać Emanuela Laskera - szachowego mistrza świata z okresu międzywojennego (HOFFMAN 2014). Czynniki te są w wielu przypadkach podstawowym motywem tworzonych produktów turystycznych. Klasycznymi przykładami są chociażby: Miejski Szlak Turystyczny im. Emanuela Laskera, coroczne wybory królowej Puszczy Barlineckiej, czy też Błękitna Trasa Legend, nawiązująca do fabuły baśni Romany Kaszczyc.

Jednym z podstawowych elementów infrastruktury turystycznej jest baza noclegowa. Uzyskane w Centrum Informacji Turystycznej dane wykazały, że w przypadku Barlinka, nie wliczając kwater prywatnych, tworzy ją 18 obiektów noclegowych. W lipcu 2017 r. miasto dysponowało około 1100 miejscami noclegowymi. Były to wszystkie rodzaje obiektów noclegowych wyszczególnione w Ustawie z 29 sierpnia 1997 r. o ustugach turystycznych, o ustugach hotelarskich oraz ustugach pilotów wycieczek i przewodników turystycznych, z wyjątkiem moteli. Do najbardziej znanych należy trzygwiazdkowy hotel „Alma Spa” i pensjonat „Pod Sosnami”, będący najstarszym obiektem noclegowym w mieście.

Ważnym elementem infrastruktury turystycznej jest także baza gastronomiczna. Według danych uzyskanych w Centrum Informacji Turystycznej w lipcu 2017 r. w Barlinku znajdowało się ponad 20 obiektów gastronomicznych, w większości restauracji i jadłodajni. Łaccznie lokale te dysponowały około 1200 miejscami konsumenckimi. Najpopularniejsze $\mathrm{z}$ nich to restauracja "Stara Galeria”, znana z tego, że jest w niej organizowanych wiele wydarzeń kulturalnych, oraz lodziarnia „Brusilewicz”, przyciągająca tłumy klientów z pobliskich miejscowości.

Baza paraturystyczna składa się z obiektów przeznaczonych do spełniania innych potrzeb społeczno-gospodarczych zarówno turystów, jak i samych mieszkańców (KACZMAREK, STASIAK, WŁODARCZYK 2010). W przypadku Barlinka bazę tę tworzą głównie obiekty sportowo-rekreacyjne. Najbardziej charakterystyczne mają związek z Jeziorem Barlineckim, bowiem są to kąpieliska i wypożyczalnie sprzętów wodnych. Znanym obiektem jest także stadion miejski im. Bronisława Bagińskiego. Poza tym na bazę paraturystyczną Barlinka składają się obiekty infrastruktury społecznej, tzn. sklepy, banki, szpital, przychodnia medyczna czy apteki. Ich liczba jest na tyle duża, że całkowicie może zaspokoić potrzeby turystów i mieszkańców.
Równie ważna jest także infrastruktura komunikacyjna. W większości przypadków dzieli się ją na infrastrukturę zewnętrzną i wewnętrzną (KUREK, MIKA 2008). Zewnętrzna infrastruktura komunikacyjna Barlinka w głównej mierze oparta jest na dwóch drogach wojewódzkich (nr 151 i nr 156) oraz kilku drogach o znaczeniu powiatowym i gminnym. Poważną wadę stanowi brak połączenia kolejowego i znikoma liczba połączeń autobusowych z pobliskimi miejscowościami. W znacznie większym stopniu rozbudowana jest infrastruktura komunikacyjna wewnętrzna. Jej najważniejszymi składowymi są szlaki turystyczne, nie tylko piesze, ale także rowerowe i wodne. Znaczące jest też funkcjonowanie tras do uprawiania nordic walkingu. Do najciekawszych szlaków należy m.in. Wodna Ścieżka na Jeziorze Barlineckim oraz Błękitna Trasa Legend, nawiązująca do fabuły legend autorstwa Romany Kaszczyc (Aktywny wypoczynek... 2017). Dużym problemem jest jednak niewielka liczba parkingów, co w znacznym stopniu utrudnia dotarcie do wielu miejsc, takich jak chociażby zabytkowe kąpielisko „Pod Sosnami", czy też rynek miejski.

Bardzo ważnym elementem przestrzeni turystycznej są ludzie. Jedną z istotnych grup stanowią mieszkańcy odpowiedzialni za organizację danej przestrzeni i zarządzanie nią. W przypadku Barlinka najważniejszym podmiotem jest Barlinecki Ośrodek Kultury, nadzorujący bezpośrednio działalność Centrum Informacji Turystycznej i Muzeum Regionalnego. Instytucje te opracowują strategie rozwoju turystyki w mieście, a także są odpowiedzialne za prowadzenie wszelkich działań promujących Barlinek. Nadzorują również rozwój infrastruktury turystycznej. Nieco mniejszą rolę w kreowaniu przestrzeni turystycznej Barlinka odgrywają władze samorządowe oraz obiekty noclegowe, gastronomiczne i sportowo-rekreacyjne.

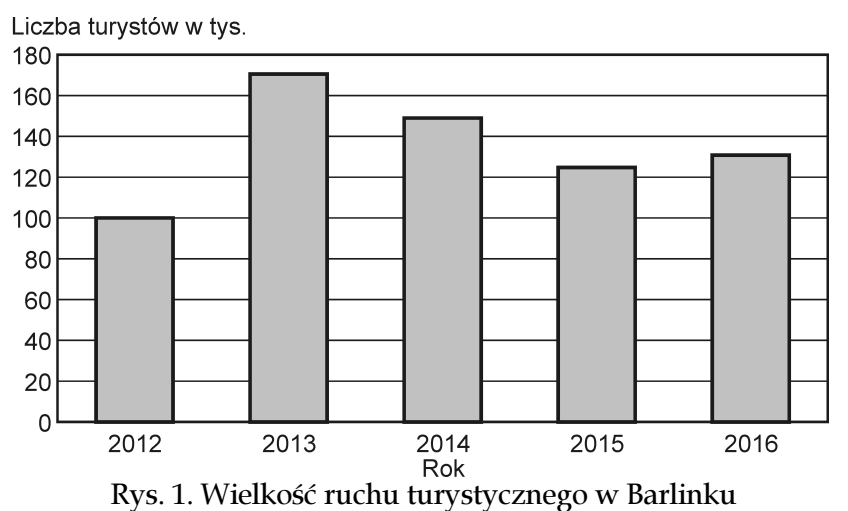

Rys. 1. Wielkość ruchu turystycznego w Barlinku w latach 2012-2016

Źródło: opracowanie własne na podstawie danych uzyskanych w Centrum Informacji Turystycznej w Barlinku

Drugą z ważnych grup są przyjeżdżający do Barlinka turyści. W trakcie prowadzenia badań uzyskano statystyki dokumentujące wielkość ruchu turystycz- 
nego w Barlinku w latach 2012-2016 (rys. 1). Dane te opracował personel Centrum Informacji Turystycznej na podstawie kwestionariuszy ankiet pozyskanych z poszczególnych obiektów noclegowych. Średnia wielkość ruchu turystycznego w latach 2012-2016 wyniosła blisko 13 tys. turystów. Najwięcej turystów odwiedziło Barlinek w roku 2013 (prawie 18 tys.).

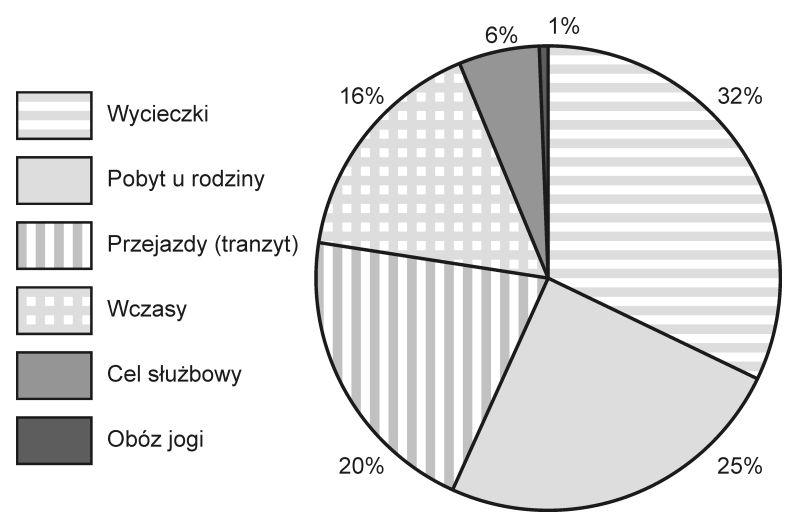

Rys. 2. Charakter pobytu turystów w Barlinku Źródło: opracowanie własne na podstawie badań ankietowych przeprowadzonych w lipcu $2017 \mathrm{r}$.

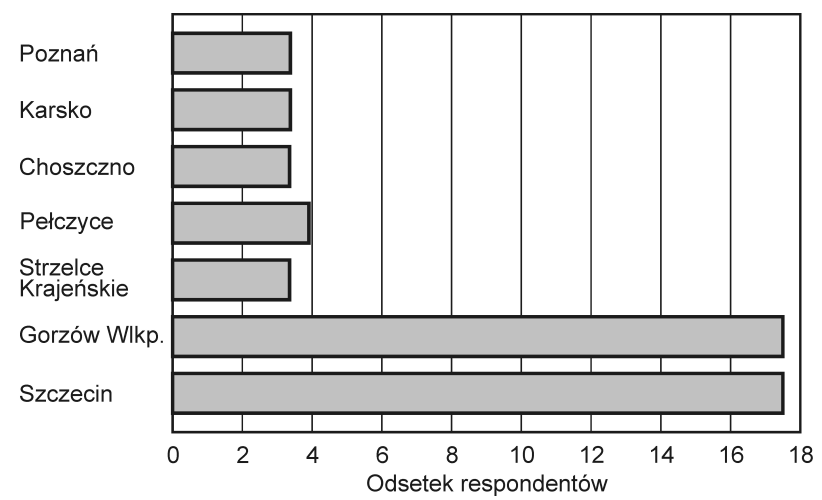

Rys. 3. Najczęściej występujące miejsce zamieszkania respondentów z Polski (w\%)

Źródło: opracowanie własne na podstawie badań ankietowych przeprowadzonych w lipcu 2017 r.

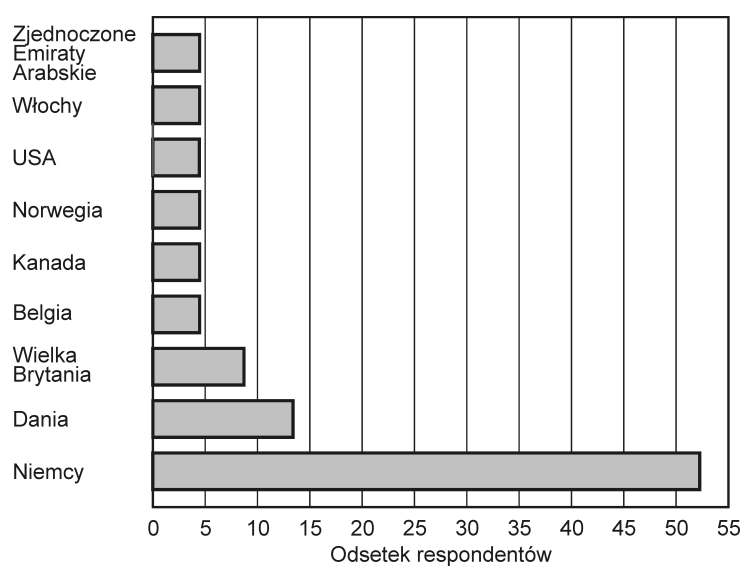

Rys. 4. Kraje pochodzenia turystów biorących udział w ankiecie Źródło: opracowanie własne na podstawie badań ankietowych przeprowadzonych w lipcu $2017 \mathrm{r}$.
Badania ankietowe, przeprowadzone wśród turystów, wykazały, że Barlinek jest destynacją przede wszystkim dla osób z pobliskich miejscowości województwa zachodniopomorskiego i lubuskiego, posiadających w tym mieście rodzinę bądź przyjaciół, oraz turystów z Niemiec i krajów skandynawskich, w szczególności z Danii (rys. 2-4).

\section{PRZESTRZEŃ TURYSTYCZNA BARLINKA W ODNIESIENIU DO KONCEPCJI I UKŁADU MODELOWEGO MIEJSKIEJ PRZESTRZENI TURYSTYCZNEJ}

Badacze opracowali dotychczas wiele koncepcji związanych z przestrzenią turystyczną. $W$ niniejszym artykule wzięto pod uwagę koncepcję zaprezentowaną przez S. LISZEWSKIEGO (1995) oraz układ modelowy miejskiej przestrzeni turystycznej autorstwa $\mathrm{B}$. WŁODARCZYKA (2011).

S. LISZEWSKI (1995) jako jeden z pierwszych badaczy opracował koncepcje podziału przestrzeni turystycznej. Klasyfikacji tej dokonal, biorąc pod uwagę następujące elementy: natężenie ruchu turystycznego, zagospodarowanie turystyczne, funkcja turystyczna oraz wpływ turystyki na stan środowiska naturalnego (tab. 1). Na tej podstawie wyróżnił takie typy przestrzeni turystycznych, jak: eksploracji, penetracji, kolonizacji, urbanizacji i asymilacji. Koncepcja ta jest uniwersalna, bowiem odnosi się do wszystkich przestrzeni turystycznych, nie tylko do miejskich.

Opierając się na wspomnianej koncepcji, można stwierdzić, że jednoznaczne wskazanie typu przestrzeni turystycznej Barlinka nie jest zadaniem prostym. W chwili obecnej przestrzeń ta jest częściowo przestrzenią penetracji turystycznej, a po części - kolonizacji turystycznej. Niektóre elementy, jak chociażby zagospodarowanie turystyczne, pozwalają uznać ją za przestrzeń kolonizacji, jednak natężenie ruchu turystycznego z nim związanego jest stosunkowo małe. Badania autora udowodniły, że $\mathrm{w}$ przyszłości barlinecka przestrzeń turystyczna może $\mathrm{w}$ pełni stać się przestrzenią kolonizacji turystycznej. W Barlinku można dopatrzeć się również przestrzeni asymilacji turystycznej. Charakteryzuje się ona $\mathrm{w}$ głównej mierze odmienną rolą turystów $\mathrm{w}$ konsumowaniu przestrzeni. Turyści są przede wszystkim gośćmi, zajmują istniejące już siedliska, czy też korzystają z usług klasycznych letnisk i kwater agroturystycznych. Często odwiedzają też swoje rodziny i znajomych. Relacje pomiędzy turystami a mieszkańcami są mniej formalne (WŁODARCZYK 2009). W przypadku Barlinka duża część turystów przyjeżdża właśnie w celu odwiedzenia rodziny bądź przyjaciół (por. rys. 2). 
Tab. 1. Charakterystyka typów przestrzeni turystycznej według S. LISZEWSKIEGO (1995)

\begin{tabular}{|l|c|c|c|c|}
\hline \multirow{2}{*}{ Typ przestrzeni } & \multicolumn{4}{|c|}{ Cechy charakterystyczne } \\
\cline { 2 - 5 } & $\begin{array}{c}\text { natężenie ruchu } \\
\text { turystycznego }\end{array}$ & $\begin{array}{c}\text { zagospodarowanie } \\
\text { turystyczne }\end{array}$ & $\begin{array}{c}\text { główna funkcja } \\
\text { turystyczna }\end{array}$ & $\begin{array}{c}\text { wpływ działalności turystycznej } \\
\text { na środowisko naturalne }\end{array}$ \\
\hline Eksploracji & minimalne & brak & poznawcza & nieszkodliwa \\
\hline Penetracji & $\begin{array}{c}\text { zróżnicowane, od } \\
\text { małego do masowego }\end{array}$ & niewielkie & $\begin{array}{c}\text { poznawczo- } \\
\text {-wypoczynkowa }\end{array}$ & uciążliwa \\
\hline Asymilacji & średnie & średnie & $\begin{array}{c}\text { wypoczynkowo- } \\
\text {-poznawcza }\end{array}$ & obojętna \\
\hline Kolonizacji & duże & duże & wypoczynkowa & przekształcająca (szkodliwa) \\
\hline Urbanizacji & średnie & duże & mieszkaniowa & degradująca \\
\hline
\end{tabular}

Źródło: S. LISZEWSKI (1995, s. 99).

Fakt ten sprawia, że o przestrzeni asymilacji turystycznej można mówić bardziej w oparciu o relacje pomiędzy turystami a mieszkańcami, niż o aspekty ściśle związane ze stanem infrastruktury turystycznej.

Kilkanaście lat po zaprezentowaniu opisanej w artykule koncepcji przez S. Liszewskiego B. WŁODARCZYK (2011) opracował układ modelowy miejskiej przestrzeni turystycznej. W swoich rozważaniach wyróżnił m.in. miasta generujące ruch turystyczny, miasta recepcyjne ruchu turystycznego, czy też tzw. miasta tranzytowe (rys. 5).

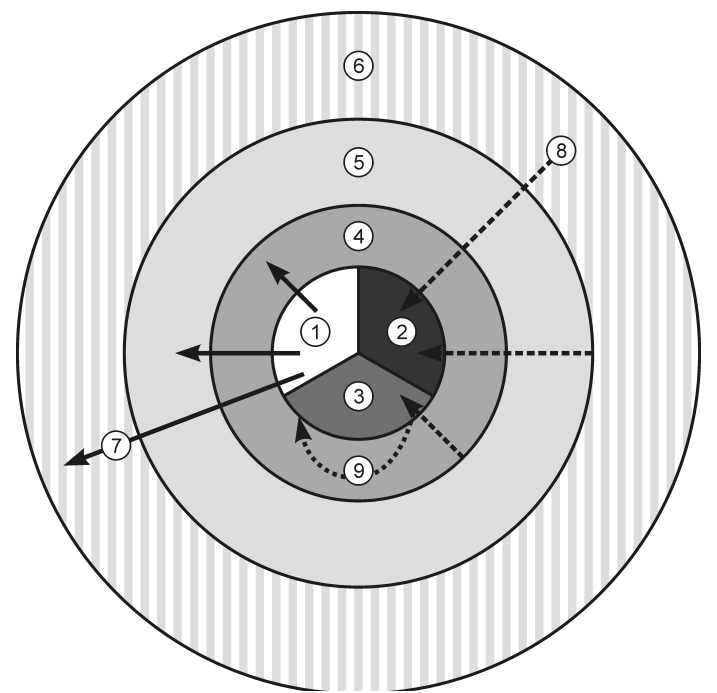

\begin{tabular}{|c|c|}
\hline & $\begin{array}{l}\text { Miasta głównie generując } \\
\text { ruch turystyczny }\end{array}$ \\
\hline & $\begin{array}{l}\text { Miasta ośrodki recepcyj } \\
\text { ruchu turystycznego }\end{array}$ \\
\hline & Miasta tranzytowe \\
\hline (4) & $\begin{array}{l}\text { Turystyczna przestrzeń } \\
\text { podmiejska bliższa }\end{array}$ \\
\hline (5) & $\begin{array}{l}\text { Turystyczna przestrzeń } \\
\text { podmiejska dalsza }\end{array}$ \\
\hline
\end{tabular}

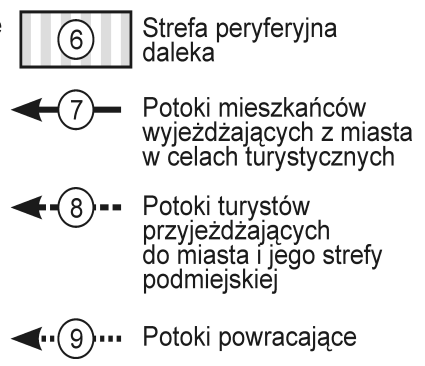

Rys. 5. Miejsce Barlinka w modelu miejskiej przestrzeni turystycznej

Źródło: opracowanie własne na podstawie B. WŁODARCZYK (2011)
Przeprowadzone badania wykazały, że Barlinek może być klasyfikowany jako miasto recepcyjne dla turystów oraz jako ośrodek tranzytowy (rys. 5). Znalazło to odzwierciedlenie w odpowiedziach udzielonych przez turystów w trakcie badania ankietowego. Większość respondentów jako główne motywy przyjazdu do Barlinka wskazała wypoczynek oraz chęć odwiedziny rodziny i przyjaciół (por. rys. 2). Analiza długości pobytów dowodzi zaś, że prawie połowa respondentów spędza w Barlinku mniej niż sześć godzin (rys. 6), co świadczy o tym, że dla wielu turystów owo miasto stanowi tranzytowy punkt ich podróży.

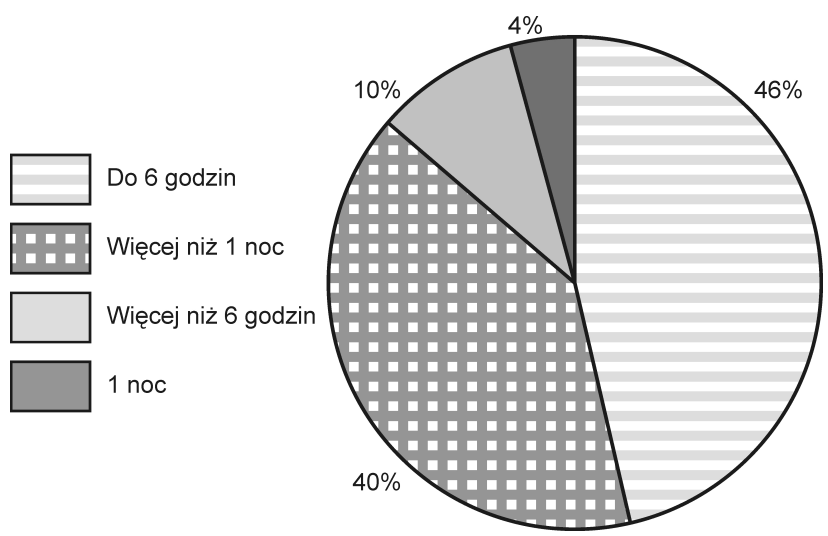

Rys. 6. Długość pobytów ankietowanych turystów Źródło: opracowanie własne na podstawie badań ankietowych przeprowadzonych w lipcu $2017 \mathrm{r}$.

B. WŁODARCZYK (2011) przyjąl, że miejską przestrzeń turystyczną tworzą takie elementy, jak: granice miasta, jego układ przestrzenny, różnego rodzaju bariery, elementy infrastruktury turystycznej oraz atrakcje turystyczne o charakterze punktowym, powierzchniowym i liniowym (rys. 7).

Analiza tych elementów pozwoliła wyróżnić różne typy miast ze względu na charakter ich przestrzeni turystycznej. W ten sposób B. WŁODARCZYK (2011) wyszczególnił miasta nieturystyczne (bez przestrzeni turystycznej), miejską przestrzeń turystyczną o charakterze 


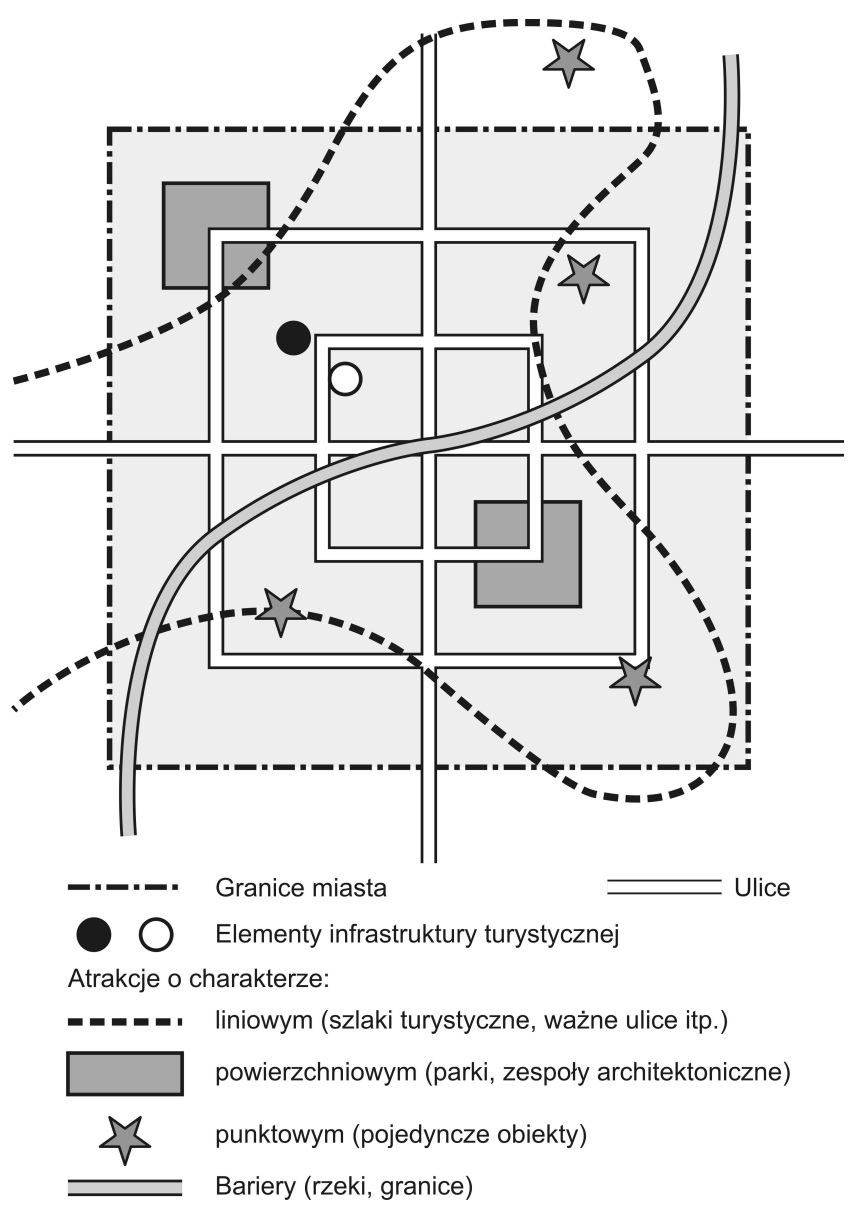

Rys. 7. Elementy tworzące miejską przestrzeń turystyczną Źródło: B. WŁODARCZYK (2011, s. 113)

ciągłym, miasta o nieciągłej przestrzeni turystycznej (pojedyncze obszary miast nie są atrakcyjne pod względem turystycznym) oraz miasta $z$ kilkoma enklawami przestrzeni turystycznej (tylko niektóre obszary są atrakcyjne turystycznie). Przestrzeń turystyczna Barlinka ma charakter nieciaggły, perforowany (por. rys. 9). Najbardziej interesujące dla turystów tereny, z najintensywniej rozwiniętą infrastrukturą turystyczną, są położone $\mathrm{w}$ centrum miasta oraz przy północno-zachodnim, północnym i północno-wschodnim brzegu Jeziora Barlineckiego (rys. 8).

$\mathrm{Na}$ podstawie zależności pomiędzy elementami kształtującymi miejską przestrzeń turystyczną wyróżniono kilka innych rodzajów miejskich przestrzeni turystycznych. Przygotowując niniejszy artykul, autor opracował plan Barlinka, na którym zamieścił wszystkie te elementy (rys. 8). Wspomagając się tą mapą, mógł on zaklasyfikować turystyczną przestrzeń Barlinka do modeli opracowanych przez B. WŁODARCZYKA (2011).

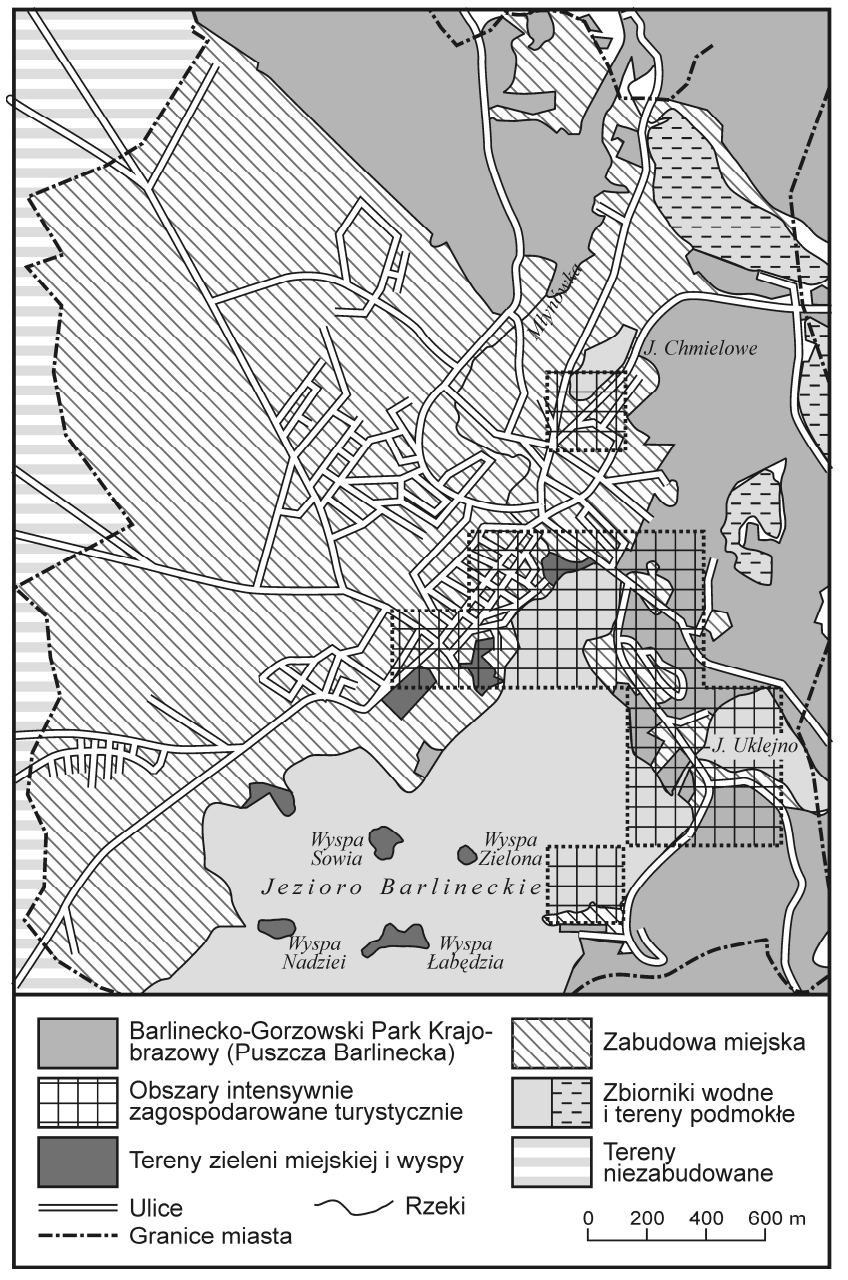

Rys. 8. Obszary Barlinka intensywnie zagospodarowane turystycznie

Źródło: opracowanie własne na podstawie https://www.barlinek24.pl/... oraz http://www.geoportal.gov.pl/

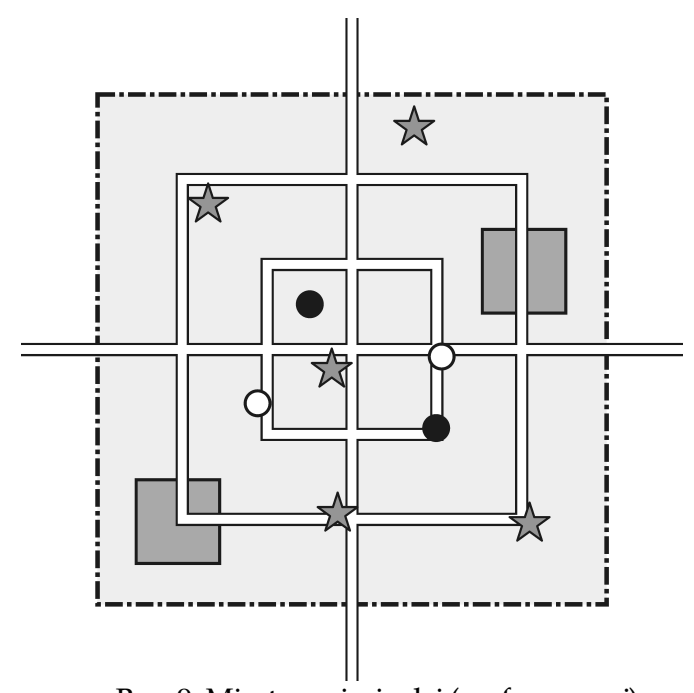

Rys. 9. Miasto o nieciągłej (perforowanej) przestrzeni turystycznej

Źródło: B. WŁODARCZYK (2011, s. 113) 
Kolejnym kryterium decydującym o charakterze miejskiej przestrzeni turystycznej jest lokalizacja atrakcji turystycznych $w$ układach przestrzennych miast. W tym przypadku wyróżniono miasta, w których atrakcje te położone są centralnie, oraz takie, w których umiejscowione są peryferyjnie (WŁODARCZYK 2011). Po dokonanej analizie przestrzeni turystycznej Barlinka stwierdzono, że większość atrakcji turystycznych znajduje się w centrum miasta (rys. 10). Najbardziej charakterystyczne jest centralne położenia takich atrakcji, jak rynek miejski czy Jezioro Barlineckie.

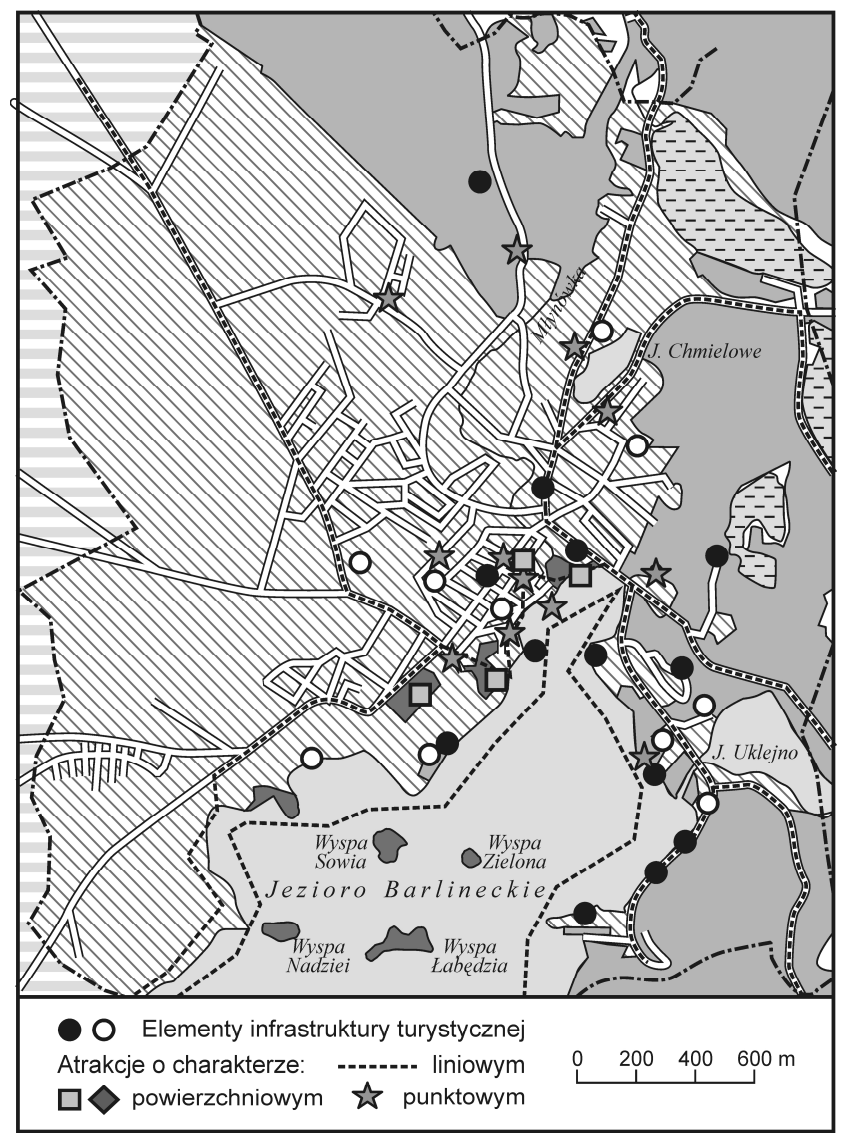

Rys. 10. Elementy miejskiej przestrzeni turystycznej Barlinka Źródło: opracowanie własne na podstawie https:/ / www.barlinek24.pl/ ... oraz http://www.geoportal.gov.pl/

Ze względu na charakter, liczebność i wzajemne położenie elementów B. WŁODARCZYK (2011) wyróżnił miasta $\mathrm{z}$ jedną wiodącą atrakcją turystyczną, miasta o policentrycznym charakterze przestrzeni turystycznej, miasta o charakterze pasmowo-węzłowym oraz miasta z rozproszonymi atrakcjami turystycznymi. Przykład Barlinka pokazał, że można go określić jako miasto o pasmowo-węzłowym charakterze przestrzeni turystycznej (rys. 11), ponieważ wszystkie atrakcje turystyczne i elementy infrastruktury turystycznej stanowią węzły połączone ze sobą pasmami w postaci wytyczonych dróg komunikacyjnych i szlaków turystycznych.

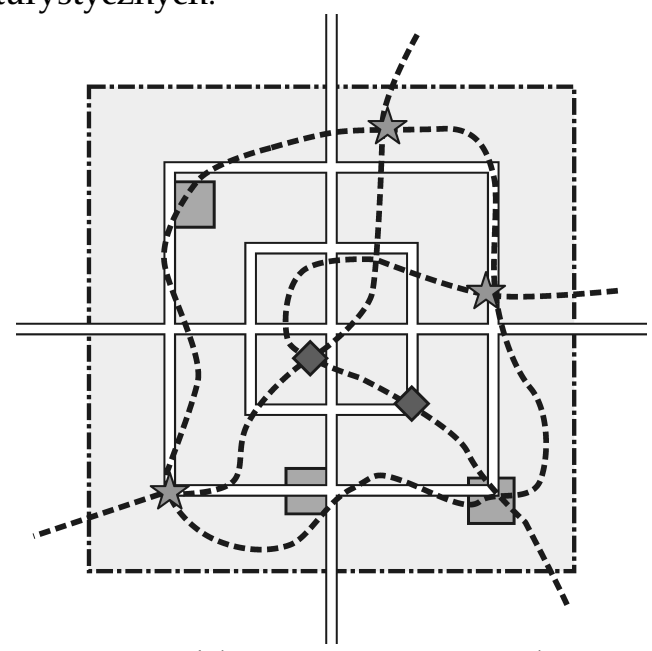

Rys. 11. Model miasta o pasmowo-węzłowym charakterze przestrzeni turystycznej Źródło: B. WŁODARCZYK (2011, s. 114)

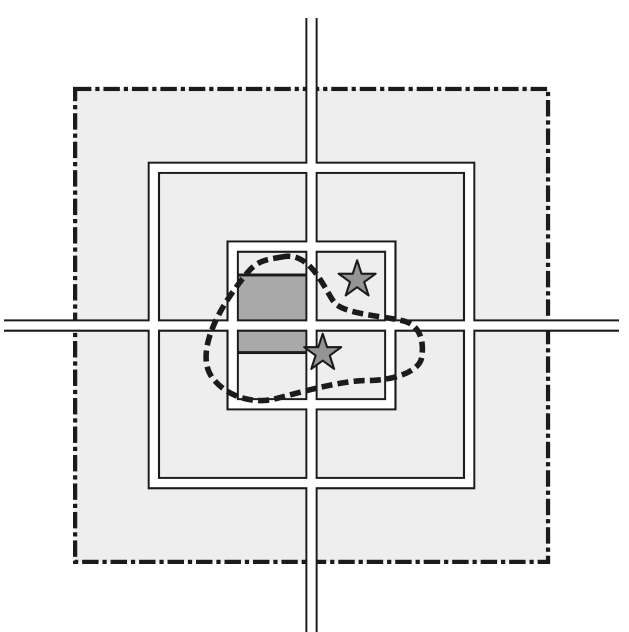

Rys. 12. Model miasta z centralnie położonymi atrakcjami turystycznymi

Źródło: B. WŁODARCZYK (2011, s. 114)

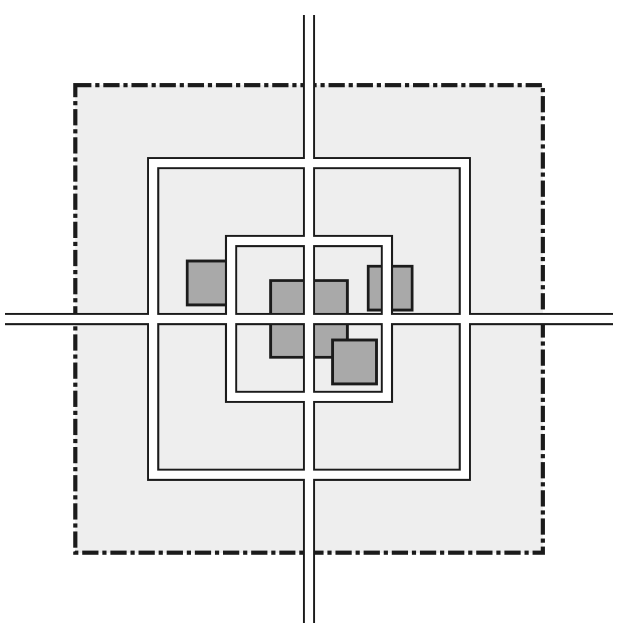

Rys. 13. Model miasta z jedną wiodącą atrakcją w przestrzeni turystycznej

Źródło: B. WŁODARCZYK (2011, s. 114) 
Atrakcje turystyczne oraz ich znaczenie pozwoliły również na wyróżnienie miast $\mathrm{z}$ widoczną dominacją jednej atrakcji oraz takich, w których elementy te mają równorzędne znaczenie. W Barlinku zwraca uwage wyraźna dominacja Jeziora Barlineckiego jako głównej atrakcji turystycznej (rys. 13).

Na fakt, że Jezioro Barlineckie jest wiodącą atrakcją turystyczną Barlinka, wskazują odpowiedzi udzielone w badaniach ankietowych zarówno przez mieszkańców, jak i turystów. Jezioro to uzyskało ogromną przewage nad pozostałymi najczęściej wymienianymi walorami Barlinka (rys. 14). Respondenci w odpowiedzi mogli podać maksymalnie trzy atrakcje turystyczne.

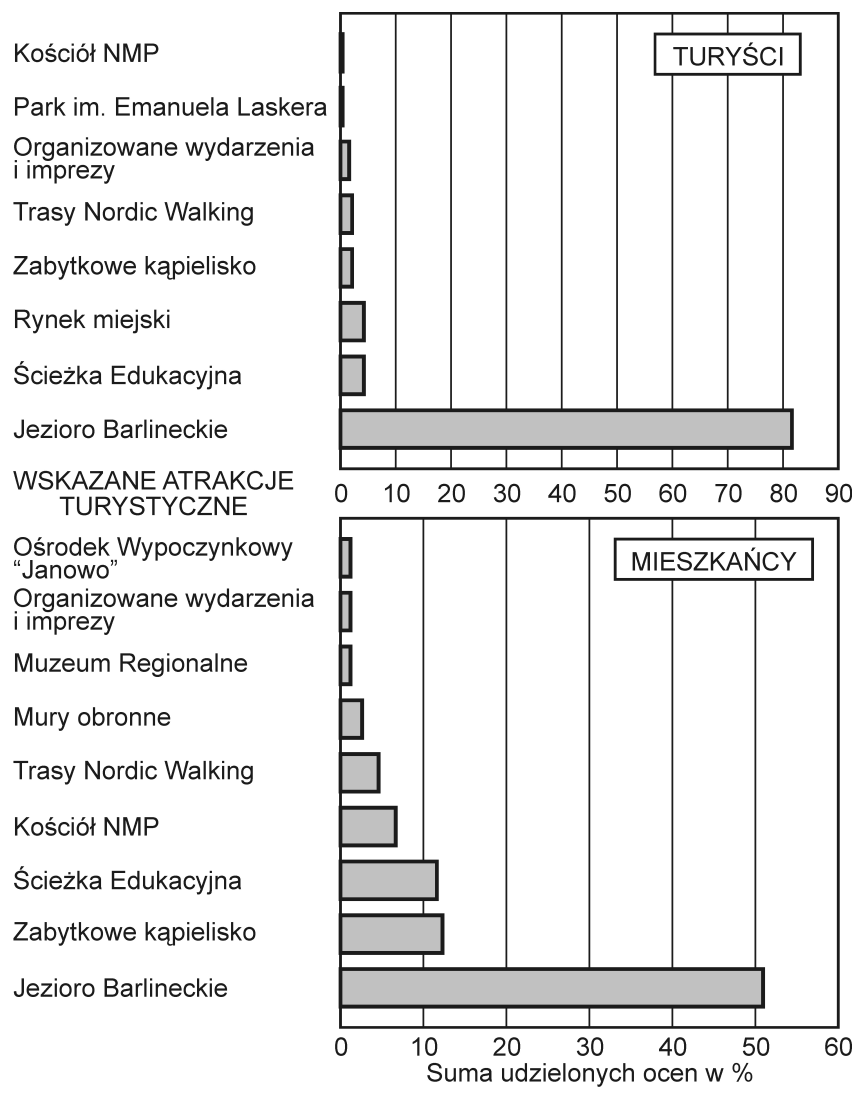

Rys. 14 . Największe atrakcje turystyczne Barlinka w opinii turystów i mieszkańców

Źródło: opracowanie własne na podstawie badań ankietowych przeprowadzonych w lipcu $2017 \mathrm{r}$.

Dominacja Jeziora Barlineckiego w liczbie wskazań jest szczególnie widoczna wśród ankietowanych turystów, bowiem takiej odpowiedzi udzieliło aż ponad 80\% respondentów. W przypadku mieszkańców Jezioro Barlineckie zostało wskazane przez nieco ponad połowę ankietowanych (rys. 14).

Ostatnie z kryteriów decydujących o charakterze miejskiej przestrzeni turystycznej stanowią zależności pomiędzy elementami kształtującymi tę przestrzeń, tzn. zależności między atrakcjami turystycznymi a infrastrukturą turystyczną. Mając na uwadze wspomniane relacje B. WŁODARCZYK (2011) wyróżnił miasta, w których o charakterze przestrzeni turystycznej decydują głównie: a) atrakcje turystyczne, b) infrastruktura turystyczna, c) obydwa te elementy (rys. 15). Charakter miejskiej przestrzeni turystycznej Barlinka zależy zarówno od składowych infrastruktury turystycznej, jak i atrakcji turystycznych (rys. 10 i rys. 15). Miasto dysponuje zarówno bogatym dziedzictwem przyrodniczym i kulturowym, jak również rozbudowaną infrastrukturą turystyczną (rys. 10).

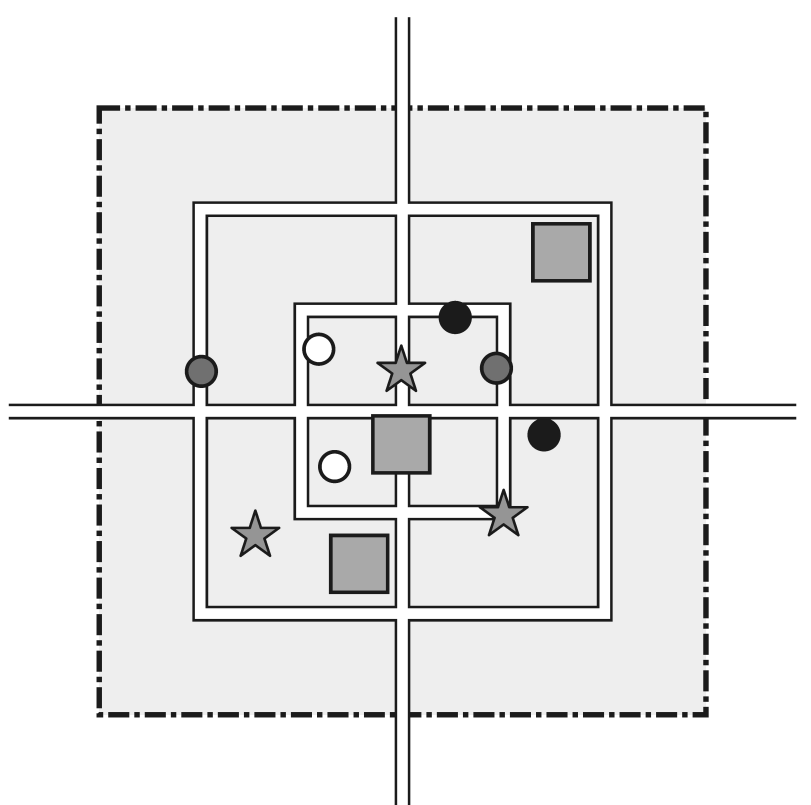

Rys. 15. Model miasta, w którym o charakterze przestrzeni turystycznej decydują atrakcje oraz infrastruktura turystyczna Źródło: B. WŁODARCZYK (2011, s. 116)

\section{POSZERZONA ANALIZA SWOT PRZESTRZENI TURYSTYCZNEJ BARLINKA}

Po zebraniu wszystkich materiałów oraz przeprowadzeniu badań terenowych przygotowano poszerzona analizę SWOT przestrzeni turystycznej Barlinka. Analiza ta, podobnie jak inne analizy SWOT, ma charakter subiektywny, bowiem oceny i wagi są przyporządkowane do poszczególnych czynników wedle poczynionych obserwacji (tab. 2-5). Wzięto pod uwagę wszystkie elementy kształtujące przestrzeń turystyczną, jak również wszystkie wnioski wysunięte na podstawie badań ankietowych z mieszkańcami i turystami. Wykonanie takiej analizy pozwoliło dokładnie opisać stan przestrzeni turystycznej Barlinka w lipcu 2017, jak i określić szanse jej rozwoju. 
Tab. 2. Poszerzona analiza SWOT przestrzeni turystycznej Barlinka - mocne strony

\begin{tabular}{|l|c|c|c|}
\hline \multicolumn{1}{|c|}{ Mocne strony } & Waga & Ocena & Srednia ważona \\
\hline \multicolumn{1}{|c|}{ Czyniki wewnętrzne } & 0,20 & 5 & 1,000 \\
\hline Dogodne położenie geograficzne (nad trzema jeziorami, na skraju Puszczy Barlineckiej) & 5 & 0,750 \\
\hline $\begin{array}{l}\text { Korzystny mikroklimat (wyższa od średniej krajowej roczna temperatura powietrza, } \\
\text { mała liczba opadów atmosferycznych) }\end{array}$ & 0,15 & 5 & 0,675 \\
\hline Dobry stan wód Jeziora Barlineckiego & 0,15 & 4,5 & 0,450 \\
\hline Promowanie Barlinka jako europejskiej stolicy nordic walkingu & 0,10 & 4,5 & 0 \\
\hline $\begin{array}{l}\text { Funkcjonowanie wielu szlaków turystycznych (tras do nordic walkingu, tras pieszych, } \\
\text { rowerowych, wodnych, tematycznych) }\end{array}$ & 0,10 & 4,5 & 0,450 \\
\hline $\begin{array}{l}\text { Występowanie zabytkowych obiektów z różnych okresów historycznych (ze średnio- } \\
\text { wiecza i z przełomu XIX i XX w.) }\end{array}$ & 0,05 & 4,5 & 0,225 \\
\hline Duże zróżnicowanie obiektów noclegowych & 0,05 & 4 & 0,200 \\
\hline Duża liczba obiektów gastronomicznych & 0,05 & 4 & 0,200 \\
\hline Dobrze rozwinięta baza towarzysząca & 0,05 & 4 & 0,200 \\
\hline Organizacja wielu wydarzeń o charakterze kulturowym i sportowym & 0,05 & 3 & 0,150 \\
\hline $\begin{array}{l}\text { Funkcjonowanie wielu produktów turystycznych, np. wybory królowej Puszczy Barli- } \\
\text { neckiej, Błękitna Trasa Legend }\end{array}$ & 0,05 & 3 & 0,150 \\
\hline Suma & $\mathbf{1 , 0 0}$ & - & $\mathbf{4 , 4 5 0}$ \\
\hline
\end{tabular}

Źródło: opracowanie własne na podstawie inwentaryzacji terenowych przeprowadzonych w lipcu 2017 r.

Tab. 3. Poszerzona analiza SWOT przestrzeni turystycznej Barlinka - słabe strony

\begin{tabular}{|c|c|c|c|}
\hline \multicolumn{4}{|l|}{ Słabe strony } \\
\hline Czynniki wewnętrzne & Waga & Ocena & Średnia ważona \\
\hline $\begin{array}{l}\text { Słaba zewnętrzna dostępność komunikacyjna (brak infrastruktury kolejowej, znikoma } \\
\text { liczba połączeń autobusowych z pobliskimi miejscowościami) }\end{array}$ & 0,30 & -3 & $-0,900$ \\
\hline Brak zagospodarowania turystycznego wokół Jeziora Uklejno i Jeziora Chmielowego & 0,20 & $-3,5$ & $-0,700$ \\
\hline Ograniczony dostęp do linii brzegowej Jeziora Barlineckiego & 0,20 & $-3,5$ & $-0,700$ \\
\hline Słabe oceny turystów dotyczące promocji turystycznej miasta & 0,05 & $-3,5$ & $-0,175$ \\
\hline Mocno rozwinięty przemysł w północnej i północno-zachodniej części miasta & 0,05 & $-3,5$ & $-0,175$ \\
\hline Duże różnice wysokości pomiędzy południową a północną częścią miasta & 0,05 & -4 & $-0,200$ \\
\hline Systematyczny spadek liczby mieszkańców & 0,05 & -4 & $-0,200$ \\
\hline Emigracja młodych mieszkańców za granicę & 0,05 & -4 & $-0,200$ \\
\hline Mała liczba miejsc parkingowych & 0,05 & -5 & $-0,250$ \\
\hline Suma & 1,00 & - & $-3,500$ \\
\hline
\end{tabular}

Źródło: opracowanie własne na podstawie inwentaryzacji terenowych przeprowadzonych w lipcu 2017 r.

Tab. 4. Poszerzona analiza SWOT przestrzeni turystycznej Barlinka - szanse

\begin{tabular}{|l|c|c|c|}
\hline \multicolumn{1}{|c|}{ Szanse } \\
\hline \multicolumn{1}{|c|}{ Czynniki zewnętrzne } & Waga & Ocena & Średnia ważona \\
\hline Rosnąca popularność aktywności turystyczno-rekreacyjnej nordic walkingu & 0,30 & 5 & 1,50 \\
\hline Rosnąca popularność wyjazdów weekendowych ludności z dużych miast & 0,20 & 4,5 & 0,90 \\
\hline Pozytywne oceny miasta w opinii większości mieszkańców & 0,20 & 4 & 0,80 \\
\hline Przyjazne relacje pomiędzy turystami a mieszkańcami & 0,10 & 4 & 0,40 \\
\hline Rozwijająca się wspótpraca Barlinka z zagranicznymi miastami partnerskimi & 0,10 & 3 & 0,30 \\
\hline Lepszy stan zagospodarowania turystycznego niż w sąsiednich miejscowościach & 0,05 & 3 & 0,15 \\
\hline Wzrastająca aktywność miasta na targach i wystawach turystycznych & 0,05 & 2 & 0,10 \\
\hline Suma & $\mathbf{1 , 0 0}$ & - & $\mathbf{4 , 1 5}$ \\
\hline
\end{tabular}

Źródło: opracowanie własne na podstawie inwentaryzacji terenowych przeprowadzonych w lipcu $2017 \mathrm{r}$. 
Tab. 5. Poszerzona analiza SWOT przestrzeni turystycznej Barlinka - zagrożenia

\begin{tabular}{|c|c|c|c|}
\hline \multicolumn{4}{|l|}{ Zagrożenia } \\
\hline Czynniki zewnętrzne & Waga & Ocena & Średnia ważona \\
\hline $\begin{array}{l}\text { Konkurencja innych turystycznych regionów pojeziernych, w szczególności Pojezierza } \\
\text { Mazurskiego }\end{array}$ & 0,25 & -2 & $-0,500$ \\
\hline Mała popularność miasta w Polsce & 0,25 & -2 & $-0,500$ \\
\hline Brak infrastruktury kolejowej i połączeń kolejowych & 0,20 & -3 & $-0,600$ \\
\hline Mała liczba połączeń autobusowych PKS z innymi miastami & 0,20 & -3 & $-0,600$ \\
\hline $\begin{array}{l}\text { Trudności we współpracy z Gorzowem Wielkopolskim ze względu na położenie miast } \\
\text { w innych województwach }\end{array}$ & 0,05 & $-4,5$ & $-0,225$ \\
\hline Mała popularność organizowanych wydarzeń (znanych jedynie w skali lokalnej) & 0,05 & -5 & $-0,250$ \\
\hline Suma & 1,00 & - & $-2,675$ \\
\hline
\end{tabular}

Źródło: opracowanie własne na podstawie inwentaryzacji terenowych przeprowadzonych w lipcu 2017 r.

Po zsumowaniu średnich ważonych mocnych i słabych stron oraz szans i zagrożeń autor zamieścił uzyskane wartości w kartezjańskim układzie współrzędnych (rys. 16).

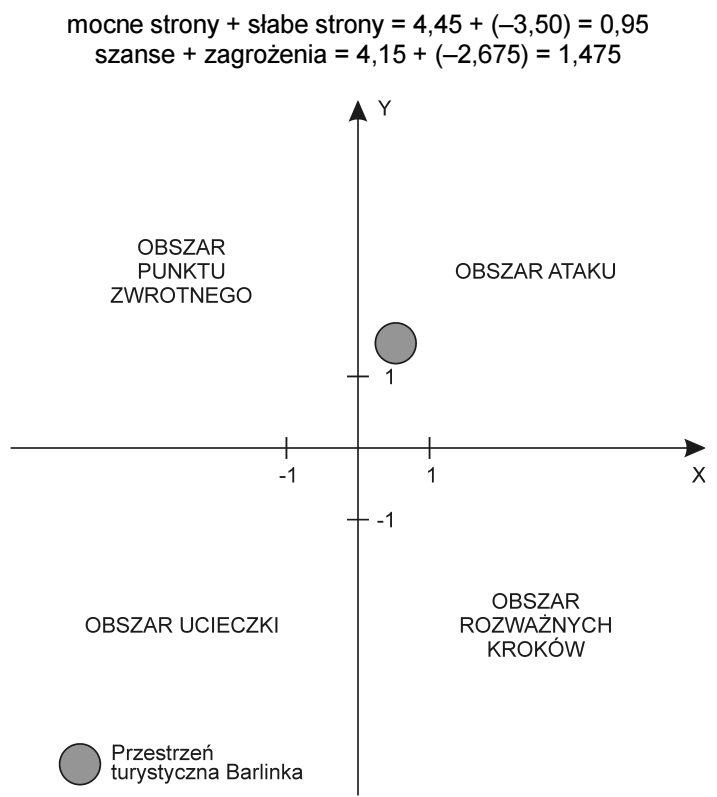

Rys. 16. Pozycja przestrzeni turystycznej Barlinka w układzie współrzędnych poszerzonej analizy SWOT

Źródło: opracowanie własne na podstawie przeprowadzonej poszerzonej analizy SWOT

Przeprowadzona analiza SWOT wykazała, że przestrzeń turystyczna Barlinka znajduje się w polu zwanym „obszar ataku”. Oznacza to, że przestrzeń ta daje duże możliwości, dzięki którym można wykorzystać wszystkie jej atuty i w przyszłości przyjmować coraz większe grupy turystów. Ponadto Barlinek powinien przyjać agresywną strategię rozwoju (tzw. maxi-maxi). Podczas realizowania tej strategii zadaniem władz miasta będzie dążenie do jak najlepszego wykorzystania pojawiających się szans, jak również bazowanie na własnych mocnych stronach.

\section{PODSUMOWANIE}

Po przeprowadzeniu analizy przestrzeni turystycznej Barlinka i umiejscowieniu jej w kontekście układów modelowych sformułowano kilka wniosków. Przede wszystkim przestrzeń turystyczna Barlinka nie obejmuje terenu całego miasta. Jest umiejscowiona $\mathrm{w}$ jego centralnej części oraz przy północno-zachodnim, północnym i północno-wschodnim brzegu Jeziora Barlineckiego. W kontekście układów modelowych, dotyczących miejskiej przestrzeni turystycznej, opracowanych przez B. WŁODARCZYKA (2011), wywnioskowano, że ma ona charakter nieciągły (perforowany), pasmowo-węzłowy. Kształtują ją jednocześnie atrakcje turystyczne i elementy infrastruktury turystycznej. Wśród atrakcji turystycznych widoczna jest zdecydowana dominacja Jeziora Barlineckiego. To właśnie ono uważane jest przez większość turystów i mieszkańców za główną atrakcję miasta i stanowi swego rodzaju wizytówkę Barlinka.

Według typów przestrzeni turystycznych opracowanych przez S. LISZEWSKIEGO (1995) przestrzeń ta jest częściowo przestrzenią penetracji, a po części kolonizacji turystycznej. Trudno ją jednoznacznie zaklasyfikować, jednakże dzięki dalszemu rozwojowi w nieodległej przyszłości może się ona stać w pełni przestrzenią kolonizacji turystycznej.

Najczęściej Barlinek stanowi dla turystów, głównie dla uprawiających aktywność turystyczno-rekreacyjną nordic walking, docelowe miejsce podróży. Niekiedy jednak staje się tranzytowym punktem podróży, zwłaszcza dla osób przyjeżdżających tu w odwiedziny do rodziny lub przyjaciół.

Poszerzona analiza SWOT przestrzeni turystycznej Barlinka wykazała, że dzięki odpowiednio prowadzonym działaniom przestrzeń ta może $\mathrm{w}$ dalszym ciągu rozwijać się w aspekcie terytorialnym, ilościowym i jakościowym. Poza tym stan infrastruktury turystycznej, 
zwłaszcza bazy paraturystycznej, sprawia, że przestrzeń ta jest w pełni przystosowana do uprawiania różnorodnych form turystyki. W największym stopniu można tam uprawiać aktywną turystykę wypoczynkową oraz nordic walking. Ponadto możliwe jest też uprawianie turystyki wodnej i rowerowej.

\section{BIBLIOGRAFIA}

Aktywny wypoczynek w Barlinku/Aktive Erholung in Barlinek, Centrum Informacji Turystycznej - BOK, 2017, ZAPOL Sobczyk s.j., Szczecin.

BORYCZKA J., STOPA-BORYCZKA M., 2005, Klimat, [w:] K. Ostaszewska, A. Richling (red.), Geografia fizyczna Polski, Wydawnictwo Naukowe PWN SA, Warszawa, s. 114-116.

CZOPEK L., PIESZCZACHOWICZ J., 2001, Popularna encyklopedia powszechna, t. 2, Grupa Wydawnicza Bertelsmann Media, Warszawa.

HoffMAN K., 2014, Szlakiem Szachowego Mistrza Świata Emanuela Laskera, Studio CD, Gorzów Wielkopolski.

HUSBANDS W.C., 1983, Tourists space and tourist attraction, an analysis of the destination choices of European travelers, "Leisure Sciences", 5, 4, s. 289-307.

JACKOWSKI A., WARSZYŃSKA J., 1978, Podstawy geografii turyzmu, Państwowe Wydawnictwo Naukowe, Warszawa.

KACZMAREK J., STASIAK A., WŁODARCZYK B., 2010, Produkt turystyczny. Pomyst, organizacja, zarządzanie, Polskie Wydawnictwo Ekonomiczne, Warszawa.
KONDRACKI J., 1998, Geografia regionalna Polski, Wydawnictwo Naukowe PWN, Warszawa.

KUREK W., MIKA M., 2008, Pojęcia podstawowe, [w:] W. Kurek (red.), Turystyka, Wydawnictwo Naukowe PWN, Warszawa, s. 24-27.

LISZEWSKI S., 1995, Przestrzeń turystyczna, „Turyzm”, 5, 2, s. 87103.

MiELCAREK K., 2006, Barlinek. 60 Lat Parafii pw. Niepokalanego Serca Najświętszej Maryi Panny, PPH ZAPOL Dmochowski, Sobczyk s.j., Szczecin.

MielCAREK K., PRZYBYLSKI G., 2009, Wodna Ścieżka Przyrodnicza na Jeziorze Barlineckim, Studio CD, Gorzów Wielkopolski.

MiosSEC J.M., 1976, Elements pour une teorie de l'espace touristique, "Centre des Hautes Etudes Touristiques", C, 36 [BB1], s. 41-48.

PRZYBYLSKI G., SKAZIŃSKI B., 2014, Dzieje Barlinka, [w:] B. Skaziński (red.), Barlinek na szlaku mtynów, Wyd. ZAPOL, Szczecin, s. 27-44.

STALSKI M., 1984, Użytkowanie ziemi w turystyce, „Przegląd Zagranicznej Literatury Geograficznej", 2, s. 139-148.

Ustawa z dnia 29 sierpnia 1997 r. o ustugach hotelarskich oraz ustugach pilotów wycieczek i przewodników turystycznych, 1997, DzU, nr 33, poz. 884.

WŁODARCZYK B., 2009, Przestrzeń turystyczna - istota, koncepcje, determinanty rozwoju, Wydawnictwo Uniwersytetu Łódzkiego, Łódź.

WŁODARCZYK B., 2011, Miasto i przestrzeń turystyczna, [w:] B. Włodarczyk (red.), Turystyka. Księga jubileuszowa w 70. rocznice urodzin profesora Stanistawa Liszewskiego, Wydawnictwo Uniwersytetu Łódzkiego, s. 105-120.

https:// www.barlinek24.pl/images/stories/plan_miasta_d.jpg; 2.05.2018.

http://www.geoportal.gov.pl/; 30.05.2018. 